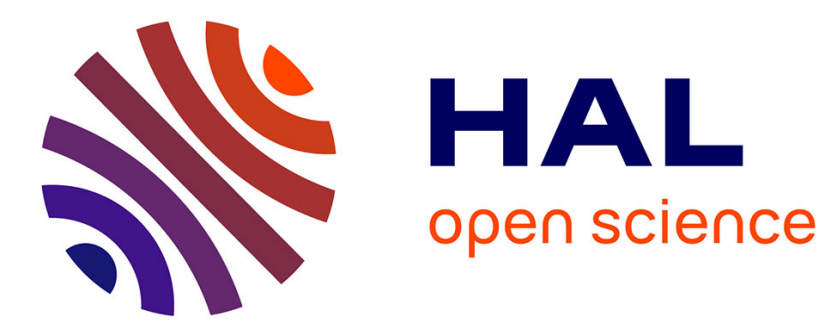

\title{
Endocrine immune interactions in human parturition
}

\author{
E. Golightly, H.N. Jabbour, J.E. Norman
}

\section{To cite this version:}

E. Golightly, H.N. Jabbour, J.E. Norman. Endocrine immune interactions in human parturition. Molecular and Cellular Endocrinology, 2011, 335 (1), pp.52. 10.1016/j.mce.2010.08.005 . hal00670736

\section{HAL Id: hal-00670736 \\ https://hal.science/hal-00670736}

Submitted on 16 Feb 2012

HAL is a multi-disciplinary open access archive for the deposit and dissemination of scientific research documents, whether they are published or not. The documents may come from teaching and research institutions in France or abroad, or from public or private research centers.
L'archive ouverte pluridisciplinaire HAL, est destinée au dépôt et à la diffusion de documents scientifiques de niveau recherche, publiés ou non, émanant des établissements d'enseignement et de recherche français ou étrangers, des laboratoires publics ou privés. 


\section{Accepted Manuscript}

Title: Endocrine immune interactions in human parturition

Authors: E. Golightly, H.N. Jabbour, J.E. Norman

PII:

DOI:

S0303-7207(10)00419-3

Reference: doi:10.1016/j.mce.2010.08.005

MCE 7617

To appear in: $\quad$ Molecular and Cellular Endocrinology

Received date: $\quad 3-8-2010$

Accepted date: $\quad$ 5-8-2010

Please cite this article as: Golightly, E., Jabbour, H.N., Norman, J.E., Endocrine immune interactions in human parturition, Molecular and Cellular Endocrinology (2010), doi:10.1016/j.mce.2010.08.005

This is a PDF file of an unedited manuscript that has been accepted for publication. As a service to our customers we are providing this early version of the manuscript. The manuscript will undergo copyediting, typesetting, and review of the resulting proof before it is published in its final form. Please note that during the production process errors may be discovered which could affect the content, and all legal disclaimers that apply to the journal pertain. 


\section{Endocrine immune interactions in human parturition}

Golightly $\mathrm{E}^{\mathrm{a}}$, Jabbour $\mathrm{HN}^{\mathrm{b}}$ and Norman $\mathrm{JE}^{\mathrm{a}}$.

${ }^{a}$ University of Edinburgh Division of Reproductive and Developmental Sciences and

${ }^{\mathrm{b}}$ The Medical Research Council Human Reproductive Sciences Unit, Centre for Reproductive Biology, The Queen's Medical Research Institute, 47 Little France Crescent, Edinburgh EH16 4TY.

Correspondence to: Prof JE Norman

Division of Reproductive and Developmental Sciences,

University of Edinburgh

Centre for Reproductive Biology,

47 Little France Crescent,

Edinburgh EH16 4TJ

Telephone: +44(0) 1312426623

Fax: +44(0) 1312426610

Email: jane.norman@ed.ac.uk

\section{Words in text 4120}




\section{Abstract}

Human parturition is an inflammatory event, modulated and influenced by a host of other environmental and physiological processes, including the endocrine hormones. Complex bidirectional communication occurs between the two systems to bring about some of the changes that are seen in labour, an event that is not yet fully understood. Preterm birth is a major problem in obstetrics and neonatology, with dysfunctional labour or prolonged pregnancy also making increasingly significant contributions to maternal morbidity. With better understanding of normal and abnormal parturition we may be able to develop novel ways of treating these complications of pregnancy and reduce maternal and neonatal morbidity and mortality. This review discusses the crucial role that endocrine-immune interaction plays in the process of labour and in the processes of abnormal and preterm labour. We propose that amongst these complex interactions it is the immune system that is the driving force behind human parturition.

\section{Keywords}

Parturition

Endocrine

Inflammation

Immune

\section{Endocrine Immune Interactions in Parturition}

\section{Introduction}

Human pregnancy and labour are extraordinary physiological events during which the fetal allograft must first be tolerated, nourished, allowed to develop and (when it is developmentally mature enough to survive the outside world), the process of labour mounted to deliver the fetus from the mother's body. This process of human labour is an elegantly choreographed sequence of events including the remodelling and dilatation of the cervix, rupture of the fetal membranes and the onset and maintenance 
of effective uterine contractions, culminating in expulsion of the fetus and placenta. The entire process is followed by involution of the uterus. However, although some aspects of human parturition are reasonably well understood, the complexity of interactions between different systems and tissues, together with the well-documented inter-species differences that are observed, combine to ensure that a complete understanding of what initiates labour, or how it is propagated and controlled, has not yet been achieved. The importance of achieving such an understanding is, of course, so that we may be able to develop strategies to improve outcomes for women and their infants for whom the process, or its timing, becomes abnormal.

Preterm birth is the major cause of neonatal mortality and morbidity in developed countries (Norman et al., 2009b) with a rising prevalence currently of $7.6 \%$ in Scotland (Norman et al., 2009b) and 9.6\% of births worldwide (March of Dimes, 2009, Martin et al., 2006). Preterm labour (with or without preterm premature membrane rupture) is the cause of preterm birth in around $75 \%$ of women (Norman et al., 2009b). Its causes are multifactorial, with infection implicated as a major cause, although the majority of preterm births are idiopathic (Goldenberg et al., 2008, Norman et al., 2009b). In contrast, dysfunctional or delayed parturition at term may also cause significant complications including caesarean section, for which the rate is rising having increased from 9\% in 1980 in England and Wales to 21\% in 2001 (Thomas, 2001). Thus a better understanding of the physiological processes of normal and abnormal parturition may help us to develop strategies to treat these pathologies and reduce both maternal and neonatal mortality and morbidity.

Traditional concepts of parturition, and indeed the hypothesis for which there is most evidence in animals, suggest that labour is a hormonal event, driven primarily by changes in progesterone and/or cortisol synthesis. Such a model can be applied to human parturition, but fits less well. Over the last 10 years, we and others have proposed that the primary events in human parturition are inflammatory, with hormonal changes being secondary or complementary. The purpose of this review is to highlight the evidence for each model separately, and then to consider which of these events is likely to be pre-eminent.

\section{Labour as an inflammatory event}


It is not a new observation that human parturition is an inflammatory event, but in recent years there have been many exciting new developments that have helped this concept to strengthen and evolve. At its most basic level, this concept is supported by the demonstration that leukocytes, (largely neutrophils and macrophages, and also $\mathrm{T}$ cells) invade the myometrium, cervix and fetal membranes at or immediately after the onset of labour (Osman et al., 2003, Thomson et al., 1999), attracted by increased tissue expression of chemokines and cell adhesion molecules (Ledingham et al., 2001, Winkler et al., 1998). In parallel, leukocytes circulating in the peripheral blood increase their expression of cell adhesion molecule ligands such as CD11a and CD11b (Yuan et al., 2009), facilitating leukocyte emigration into the myometrium and cervix.

The increased expression of cytokines in the myometrium and cervix in labour (Osman et al., 2003) arises in part from the invading leukocytes (Young et al., 2002) with recent evidence suggesting that increased capacity of leukocytes in labour to express cytokines is initiated in the peripheral circulation (Yuan et al., 2009). These pro-inflammatory cytokines have a multitude of effects on the reproductive tissues, including stimulatory effects on myometrial contractility via a number of different mechanisms, discussed below. Cytokines are also involved in tissue remodelling (Sennstrom et al., 2000) and attract more leukocytes in a positive feedback mechanism (Elliott et al., 2000), augmenting the process of parturition. The activity of nuclear factor-kappa $\mathrm{B}(\mathrm{NF}-\mathrm{\kappa B})$, a transcription factor regulating numerous genes involved in a multitude of cellular processes including inflammation, is also increased in labour (Allport et al., 2001). The most clearly described increase in NF- $\kappa B$ in association with parturition occurs in the fetal membranes (Allport et al., 2001), although NF- $\mathrm{KB}$ is also expressed in the myometrium with obvious changes being described in pregnancy (Chapman et al., 2004). NF- $\mathrm{KB}$ may provide a feed forward mechanism for inflammatory processes in labour, given that it is itself highly inducible by pro-inflammatory stimuli (Belt et al., 1999, Kniss et al., 2001, Lappas et al., 2002).

Taken together therefore, labour is associated with leukocyte invasion, NF- $\kappa \mathrm{B}$ activation and pro-inflammatory cytokine production in some if not all of the relevant reproductive tissues. These data strongly support the hypothesis that labour is an 
inflammatory event. The functional effects of these pro-inflammatory events are described below.

\section{Myometrium}

The upregulation of pro-inflammatory cytokines within labouring myometrium stimulates and potentiates uterine contractions. Tribe et al have demonstrated that interleukin (IL)-1 $\beta$ induces basal and store operated calcium entry in myometrial smooth muscle cells, thus directly increasing their contractile potential (Tribe et al., 2003). Additionally, IL-1 $\beta$ and tumor necrosis factor (TNF)- $\alpha$ stimulate arachidonic acid release, and expression of cyclooxygenase (COX)-2 thus increasing prostaglandin production in myometrial cell cultures, via greater NF- $\kappa \mathrm{B}$ activity (Belt et al., 1999, Hertelendy et al., 1993, Molnar et al., 1993, Rauk and Chiao, 2000). Prostaglandins have long been known as stimulators of myometrial contractions (Johnston et al., 1993) thus there is a clear potential causal link between the inflammatory events observed in the myometrium and the clinical process of parturition.

\section{The cervix}

Cervical ripening is characterised by breakdown of collagen and remodelling of the connective tissue element of the cervix. Leukocyte invasion and the increase in protein concentrations of IL-8, IL-6 and granulocyte-CSF (G-CSF) observed in the human cervical connective tissue at term and subsequently in labour are likely to be crucial to the process of cervical remodelling to facilitate opening during parturition (Osman et al., 2003, Sennstrom et al., 2000). Functionally, IL-8 may stimulate the release of degradative enzymes from neutrophils. These enzymes include serine proteases and matrix metalloproteinases ((MMP)-8 and MMP-9)) (Kelly, 2002) which then participate in degradation of the collagen and glycosaminoglycan components of the extracellular matrix thereby leading to cervical ripening (Hertelendy and Zakar, 2004). Production of MMP-1, MMP-3 and MMP-9 from resident fibroblasts (Ito et al., 1991) and smooth muscle cells (Watari et al., 1999) may also be increased by IL$1 \beta$ in the cervix whilst downregulating the expression of tissue inhibitor of metalloproteinase (TIMP)-2, an endogenous inhibitor of MMP-2 (Watari et al., 1999), with these events being further amplified by NF- $\kappa B$ production. NF- $\kappa B$ itself may be 
activated via toll-like receptor (TLR)-4 by degraded extracellular matrix proteins such as fragments of fetal fibronectin, degraded during cervical remodelling, thus reinforcing the ongoing sterile inflammation of labour (Challis et al., 2009). Thus, at the end of pregnancy and during labour, the cervix having remained firm and closed despite increasing pressure during pregnancy, begins, under the influence of a host of inflammatory mediators, to soften and dilate.

\section{Fetal membranes}

A similar pro-inflammatory pattern to that observed in the myometrium is seen in the fetal membranes. The production of IL-8, TNF- $\alpha$, IL- 6 and IL-1 $\beta$ are all increased in the fetal membranes and amniotic fluid during labour (Young et al., 2002). There are also increased levels of MMP-9 (Vadillo-Ortega et al., 1995) and decreased levels of the TIMPs (Riley et al., 1999). Functionally, an increased MMP /TIMP ratio weakens the fetal membranes, facilitating fetal membrane rupture which is often the precursor to labour.

Careful examination of the fetal membranes from pre-labour specimens obtained at caesarean section has demonstrated that a zone of weakness exists in the region overlying the cervix (McLaren et al., 1999). The features of this zone include a decrease in thickness in comparison to the rest of the fetal membranes, increased MMP-9 and decreased TIMP-3 and also increased poly (ADP-ribose) polymerase -1 (PARP1) cleavage (El Khwad et al., 2005). PARP1 is an enzyme involved in DNA repair and apoptosis and thus its increase indicates increased apoptosis (El Khwad et al., 2005). It would seem therefore that towards the end of pregnancy the fetal membranes are prepared for labour by a process of remodelling to develop a weakened area that is the site of rupture. What initiates and develops this process is not known but a greater understanding of the molecular events leading to membrane rupture may lead to developing novel therapeutic strategies to halt its premature onset in preterm labour.

The fetal membranes are specifically important, as they are the interface between the fetus and the mother, and may transmit pro-labour signals from the baby to the 
mother's myometrium and cervix. Pulmonary derived surfactant proteins and phospholipids may be key to this: as the fetus matures, increased quantities are produced and so levels increase in the amniotic fluid. These surfactant proteins may well contribute to the inflammatory response that can be observed in the fetal membranes and in the underlying cervix and myometrium (Smith, 2007) given that they stimulate COX-2 activity via TLR-4 in mice (Wang and Hirsch, 2003) and subsequent prostaglandin E2 (PGE2) production in the amnion. Increased PGE2 production in the amnion could diffuse through the chorion and decidua to stimulate myometrial cell prostaglandin production and hence contractility (Slater et al., 1999, Smith, 2007). The fetus and placenta may also jointly trigger fetal membrane rupture, since prostaglandins, TNF- $\alpha$ and corticotrophin releasing hormone (CRH) (which also rise in the amniotic fluid towards term (Alvi et al., 1999, Laatikainen et al., 1988)) all stimulate the production of MMP-9, which weakens the membranes and thus facilitates membrane rupture (Kumar et al., 2006, Young et al., 2002).

\section{Preterm Birth and Inflammation}

Preterm labour may be initiated by a multitude of different mechanisms, including infection, placental haemorrhage, cervical insufficiency, and uterine over-distention. The cause is multi-factorial and is often idiopathic; however, infection is the single biggest aetiological factor (Goldenberg et al., 2008). Micro-organisms such as Escherichia coli, Ureaplasma urealyticum and Streptococcus agalatae are receognised by the TLRs, which stimulate increased production of inflammatory cytokines at least in part by NF- $\mathrm{BB}$ and initiate the cascade of inflammatory events described above, resulting in preterm parturition (Peltier, 2003).

Several animal models of parturition involve stimulation with pro-inflammatory substances such as lipopolysaccharide (LPS) to mimic the onset of preterm labour (Elovitz et al., 2003, Fidel et al., 1994). Such animal models have helped to develop potential new strategies for treating preterm birth. The importance of inflammation is demonstrated by experiments showing that the anti-inflammatory agent IL-10 not only prevents preterm birth, but also prevents neonatal brain damage in rats (RodtsPalenik et al., 2004, Terrone et al., 2001). More recently, Bennett's group have shown 
that the anti-inflammatory prostaglandin 15-deoxy-delta(12,14)-prostaglandin $\mathrm{J}(2)$ (15d-PGJ(2)) may have similar dual effects: in their mouse model 15d-PGJ(2) inhibited both LPS induced contractions and preterm delivery and the upregulation of NF- $\kappa$ B in the fetal brain (Pirianov et al., 2009). These results encourage the possibility of the future development of agents that could be used not only to prevent preterm labour but also to protect the developing fetus from the damaging effects of surrounding inflammation.

\section{Labour as an endocrine event}

\section{Progesterone}

Progesterone sustains the state of pregnancy and maintains uterine quiescence throughout gestation. It has long been observed that in most mammalian species a fall in plasma levels of progesterone is the initiating step towards parturition. However, contrary to what is observed in other mammalian species, most human studies have demonstrated that progesterone levels in pregnancy remain constant in plasma in the late third trimester of pregnancy and during labour (Boroditsky et al., 1978, Mathur et al., 1980) The fact that the progesterone receptor antagonist mifepristone is an effective agent for induction of labour to soften the cervix and increase uterine sensitivity to uterotonic agents (Hapangama and Neilson, 2009) does suggest that a role exists for some form of progesterone withdrawal being involved in the initiation of human parturition. An alternative concept of 'functional progesterone withdrawal' has therefore been proposed for humans, in which there is loss of the quiescent effect of progesterone on myometrium, despite continuing high systemic and local levels. There have been several different mechanisms proposed for this, including local metabolism of progesterone (Mitchell and Wong, 1993), changes in ratios of the progesterone receptor isoforms (Mesiano et al., 2002) and changes in levels of cofactors affecting progesterone receptor (PR) function (Condon et al., 2003).

Progesterone can be metabolised to a less active metabolite, $20 \alpha$-dihydroprogesterone and it has been shown that production of this less active form increases after the initiation of labour (Mitchell and Wong, 1993), presenting a potential mechanism for functional progesterone withdrawal. Functional progesterone withdrawal also likely occurs at the receptor level - either via changes in progesterone receptor isoforms or 
their cofactors. The nuclear progesterone receptor exists in more than one isoform, the two major forms being progesterone receptors A and B (PR-A and PR-B). PR-B functions mainly as an activator of progesterone-responsive genes, whereas PR-A has an inhibitory action thereby suppressing PR-B function. Mesiano et al describe a model in which a change in the ratio of the receptor isoforms from a PR-B dominant mileu to a PR-A dominant one may be seen around the time of parturition (Mesiano et al., 2002), with evidence to support this hypothesis at the level both of mRNA and protein expression (Merlino et al., 2007). A multitude of cofactor proteins exist that interact with the progesterone receptor family to enhance or repress their action. Several groups have postulated that changes in the level of some of these cofactors may account for the functional progesterone withdrawal. including Condon et al who demonstrated a decline in the levels of cyclic adenosine monophosphate (cAMP)response element-binding protein (CREB)-binding protein and steroid receptor coactivators 2 and 3 in human fundal myometrium thus reducing PR transcription (Condon et al., 2003).

\section{Estrogen}

Estrogen has a stimulatory effect on contractions of human myometrium, by increasing the expression of uterine contraction associated protein (CAP)-genes such as connexin-43 and oxytocin receptors. Here again, the contrast exists between the human and other mammalian species in that in most mammals parturition is associated with an increase in circulating estrogens, but in humans, serum estrogen levels are high throughout pregnancy, gradually increasing to term (Tulchinsky et al., 1972). This increase is accelerated in the final few weeks of pregnancy but there are no significant difference in estrogen levels during labour compared to just before labour (Boroditsky et al., 1978, Turnbull et al., 1974). mRNA expression of the estrogen receptor (ER)- $\alpha$ is increased in labouring myometrium, suggesting that a functional estrogen activation may also occur, which has been linked to the functional progesterone withdrawal (Mesiano et al., 2002). Recent data from Smith and colleagues suggests that a change in estradiol/estriol ratios and progesterone to estriol ratio might be important, and that hormone trajectories in the individual may have greater impact than absolute levels. (Smith et al., 2009). 


\section{Corticotropin-releasing hormone and the "placental clock"}

Corticotropin-releasing hormone is a 41-amino acid peptide released from the hypothalamus and it regulates the hypothalamic-pituitary-adrenal (HPA) axis and plays a central role in the response to stress (Wadhwa et al., 2001). In human pregnancy, the placenta releases CRH and maternal plasma CRH levels increase exponentially, peaking at delivery, and returning to pre-pregnancy levels within 24 hours of birth (Campbell et al., 1987, Kalantaridou et al., 2004). Interestingly, placental production of $\mathrm{CRH}$ seems to occur only in primate species, again reinforcing the uniqueness of human parturition (Robinson et al., 1989). CRH binding protein (CRH-BP) produced by the liver and placenta, limits the bioavailability of $\mathrm{CRH}$ but its levels fall during the last six weeks of pregnancy leaving increased levels of free CRH (Linton et al., 1993). Women in preterm labour have significantly elevated levels of CRH compared to non-labouring women of the same gestation, a finding that can also be seen several weeks in advance of clinical signs of preterm labour (McLean et al., 1995, Wadhwa et al., 1998). Taken together, these observations form the hypothesis that $\mathrm{CRH}$ may function as a placental clock in humans, determining the length of gestation and onset of labour (McLean et al., 1995). A positive feedback loop has been proposed whereby fetal glucocorticoids, produced by the maturing fetal adrenal glands, promote placental CRH gene expression and $\mathrm{CRH}$ production, which in turn stimulates further fetal cortisol production via the HPA axis (Robinson et al., 1988). This system may also be modulated by maternal or fetal stress, which has been suggested as a possible mechanism for the increased rates of preterm delivery observed in women suffering from increased levels of stress (Wadhwa et al., 2001).

The contribution that these increasing levels of CRH may have on parturition itself is not yet certain. $\mathrm{CRH}$ signals through $\mathrm{G}$ protein-coupled receptors which exist in several different forms and use different second messenger systems to exert their effects (Grammatopoulos et al., 1995). During pregnancy the predominant CRH receptor in the myometrium is $\mathrm{CRH}$ receptor $(\mathrm{R}) 1 \alpha$, binding of which by $\mathrm{CRH}$ promotes myometrial relaxation via activation of cAMP (Grammatopoulos et al., 1994). However, this action is inconsistent with the concept of CRH functioning as a 'placental clock' and promoting labour. At term, the affinity of $\mathrm{CRH}$ for its receptor is 
reduced, and oxytocin has been implicated in promoting this reduction by inhibiting the activity of adenylate cyclase (Grammatopoulos and Hillhouse, 1999b). Thus it has been hypothesised that $\mathrm{CRH}$ may be involved in promoting contractile activity via its interaction with oxytocin (Grammatopoulos and Hillhouse, 1999a).

\section{Oxytocin}

Oxytocin and its receptor (OT and OTR) play an important role in parturition, although their precise role is as yet incompletely understood (Blanks and Thornton, 2003). Plasma concentrations of OT rise with labour (Thornton et al., 1992), as do concentrations of OT in gestational tissues (Blanks et al., 2003). Clinically, synthetic oxytocin is used to augment contractions during dystocic labour and OTR antagonists are licensed as tocolytic agents for the treatment of preterm labour (Romero et al., 2000). However, OT appears not to be an essential participant in labour as oxytocin (/-) null mice can deliver normally (Nishimori et al., 1996, Young et al., 1996). The oxytocin receptor increases at term in myometrial tissue (Fuchs et al., 1984) and its increased expression leads to direct contractile effects in myometrium (Blanks and Thornton, 2003).

\section{Preterm birth and the Endocrine System}

Progesterone supplementation has been used for many decades now to try to prevent preterm labour and reduce the severity of its neonatal sequelae (Fuchs and Stakemann, 1960). Three large randomised controlled trials have suggested that administration of progesterone reduces the risk of preterm delivery in high-risk singleton pregnancies (da Fonseca et al., 2003, Fonseca et al., 2007, Meis et al., 2003). Importantly, this effect appears to be confined to singleton pregnancies for reasons that are as yet unclear (Norman et al., 2009a, Simhan and Caritis, 2007). Currently, the reduction in preterm delivery achieved by progesterone has not been shown to be accompanied by an improvement in perinatal mortality (Dodd et al., 2008) and further studies are ongoing to explore long-term outcomes in infants whose mothers are treated antenatally with progesterone to prevent preterm delivery.

\section{Human labour is an immune not an endocrine event}


So if the onset of human labour has features of inflammation and endocrine changes, which is the predominant? There is little compelling evidence to suggest that in humans a hormonal switch exists that signals the end of pregnancy and begins the process of parturition. Unlike most animal species studied, humans do not appear to be dependent on the withdrawal of progesterone, nor on an increase in estrogen for labour to commence. Rather, it seems that a multitude of complex and interlinked processes combine to overwhelm the quiescent phase of pregnancy and initiate labour. Mitchell and Taggart have suggested a model of 'modular accumulation of physiological systems' in which multiple interlinking physiological processes develop in parallel until a critical mass is achieved which results in parturition (Mitchell and Taggart, 2009). Their model also describes how the premature and inappropriate activation of some of the 'modules' could result in preterm labour thus such a concept could explain the onset of both term and preterm human labour. We propose that the linkages between such processes are dominated by the inflammatory system and that whilst hormones play an undoubtedly vital part in human parturition, it is the immune system that is the more important driving force.

Progesterone has long been described as an 'anti-inflammatory steroid' and this is supported by a wealth of data demonstrating its interactions with the immune system. Progesterone itself inhibits IL-6 production in fetoplacental arteries (Gotkin et al., 2006), and progestogens such as medroxyprogesterone acetate inhibit a range of proinflammatory cytokines and chemokines in human myometrium (Shynlova et al., 2008, Youssef et al., 2009). Of particular interest are the interactions of progesterone with NF- $\mathrm{B}$, a transcription factor which has key functions within human parturition (Allport et al., 2001, Elliott et al., 2001). NF- $\kappa$ B activation increases in fetal membranes in labour (Allport et al., 2001) but is negatively repressed by activation of the progesterone receptor (Allport et al., 2001). In contrast, NF- $\kappa B$ itself represses progesterone receptor activity; work from Carole Mendelson's group has demonstrated that activation of NF- $\mathrm{KB}$ in human myometrium upregulates inhibitory PR isoforms (Condon et al., 2006). It may be that the removal of the immunosuppressive, quiescent influences of progesterone by the functional progesterone withdrawal may in fact itself be initiated by inflammation and activation of $\mathrm{NF}-\kappa \mathrm{B}$ (see Fig1). 
Estrogens can induce either proinflammatory or anti-inflammatory effects, depending on the immune stimuli, the cell types involved, the target organ, estrogen concentration and receptor expression (Straub, 2007). With respect to cytokine expression, estrogen in the high concentrations seen in pregnancy can inhibit proinflammatory pathways which include those activated by IL-1 $\beta$ (Polan et al., 1989), IL-6 (Keck et al., 1998, Kikuchi et al., 2000), IL-8 (Rodriguez et al., 2002) and TNF- $\alpha$ (Rogers and Eastell, 2001) as well as inhibiting the activity of natural killer cells (Seaman and Gindhart, 1979). In contrast, the secretion of 'anti-inflammatory interleukins' IL-4 (Kamada et al., 2001), IL-10 (Kanda and Tamaki, 1999) and transforming growth factor (TGF)- $\beta$ (Hatthachote and Gillespie, 1999) are stimulated by estrogen in these high levels. Notwithstanding these clear anti-inflammatory effects of estrogen, in vivo estradiol can augment the production of pro-inflammatory cytokines by CD4+ T cells (Maret et al., 2003) likely via a direct effect as circulating leukocytes express ER- $\alpha$ (Straub, 2007). Thus, although estrogen has a stimulatory effect on myometrium, it also has highly complex interactions with the immune system that may contribute to the quiescence maintained throughout pregnancy.

CRH and the HPA axis are intimately linked with the immune system and exert complex effects on the human female reproductive system (Kalantaridou et al., 2004). $\mathrm{CRH}$ has been shown to regulate cytokine production, and in return inflammatory cytokines influence CRH production. For example both TNF- $\alpha$ and IL-1 $\beta$ stimulate production of CRH (Dudley, 1999) and conversely CRH inhibits the production of IL1 and IL-6 by peripheral blood mononuclear cells (Salas et al., 1997). CRH may reduce the cytotoxicity of natural killer cells (Irwin et al., 1990) and also inhibits T cell proliferation (Jain et al., 1991). Increasing fetal cortisol production, perpetuated by increasing $\mathrm{CRH}$ production as described above, is also associated with fetal lung maturation and production of surfactant proteins and phospholipids which are present in the amniotic fluid. Such compounds are proinflammatory and it has been proposed (Smith 2007) that they might stimulate production of prostaglandins and initiation of inflammation in the fetal membranes.

The effect of inflammatory cytokines on the OTR is somewhat conflicting as described in the literature. Schmid et al reported a downregulation of OTR mRNA by IL-1 $\beta$ in a myometrial cell line (Schmid et al., 2001), and Rauk et al also reported 
down-regulation of OTR mRNA following treatment with IL-1 $\beta$ and up-regulation after treatment with IL-6 in primary human smooth muscle cells (Rauk and FriebeHoffmann, 2000, Rauk et al., 2001). However, Terzidou et al demonstrated rapid transient upregulation of OTR mRNA with treatment of primary human myocytes with IL-1 $\beta$ (Terzidou et al., 2006) which is more consistent with the actual mileu present in labour i.e. increased levels of IL-1 $\beta$, COX-2 and IL-8. The OTR promoter contains putative transcription binding sites for CCAAT/enhancer binding protein $(\mathrm{C} / \mathrm{EBP})$ and NF- $\mathrm{KB}$, which are transcription factors activated by cytokines such as IL-1 $\beta$ and IL-6 (Terzidou et al., 2006). IL-1 $\beta$ and IL-6 increase the secretion of oxytocin in uterine smooth muscle cells (Friebe-Hoffmann et al., 2001) and IL-1 $\beta$ has been observed to augment the oxytocin-stimulated contractility of myometrial strips in culture (Molnar et al., 1993). Thus, it seems likely that the result of the infiltration of inflammatory cells and increase in pro-inflammatory cytokines is to activate the myometrial tissue (at least in part via an increase in OTR expression) and to promote contractility.

\section{Strategies to treat preterm birth}

As knowledge accumulates about the mechanisms of preterm and term human labour, we can hope to come closer to an effective therapy for preventing preterm or dysfunctional labour. As described earlier, investigators have seen promising results in animal models with anti-inflammatory agents, although neither IL-10 nor 15dPGJ(2) are yet available for clinical use. Data from other animal models suggesting that progestogens may protect against traumatic and ischaemic induced brain injury (at least partly due to their inhibitory effect on pro-inflammatory cytokine production is also highly encouraging (Sayeed and Stein, 2009). Ultimately, there is still much work to be done before the mysteries of human parturition are revealed. Although we believe that the inflammatory reaction that accompanies labour is essentially the orchestrating force that drives it (Fig 2), many fascinating questions remain to be explored before this theory can be proven. Inflammation in response to intrauterine infection is an important cause of many, but not all, cases of preterm labour. How do the inflammatory signatures of infected and non-infected term and pre-term labour compare and how may this clarify potential initiators of labour? Recently published 
gene-profiling work by Weiner et al has suggested that indeed there may be differences in the initiating pathways between term and preterm labour, which will no doubt provoke further exploration of these differences.

\section{Conclusions}

The biochemical mechanisms of human parturition in which the membranes weaken and rupture, the cervix softens and effaces and the uterus is activated to produce contractions, are both highly complicated and incompletely understood. It is clear that an intricate web of interactions exists between components of the endocrine and immune systems in order to regulate this process, and that disorders within it may lead to significant complications for both mother and infant. We propose that the farreaching influences of the inflammation of labour may prove to be the key to unlocking the secrets behind human parturition and that further elucidation of these interactions between the immune and endocrine systems will help to develop strategies to treat the complications of labour that women still face.

Allport, V. C., Pieber, D., Slater, D. M., Newton, R., White, J. O. and Bennett, P. R. 2001. Human labour is associated with nuclear factor-kappaB activity which mediates cyclo-oxygenase-2 expression and is involved with the 'functional progesterone withdrawal'. Mol Hum Reprod. 7. 6. 581-6

Alvi, S. A., Brown, N. L., Bennett, P. R., Elder, M. G. and Sullivan, M. H. 1999. Corticotrophin-releasing hormone and platelet-activating factor induce transcription of the type-2 cyclo-oxygenase gene in human fetal membranes. Mol Hum Reprod. 5. 5. 476-80

Belt, A. R., Baldassare, J. J., Molnar, M., Romero, R. and Hertelendy, F. 1999. The nuclear transcription factor NF-kappaB mediates interleukin-1beta-induced expression of cyclooxygenase-2 in human myometrial cells. Am J Obstet Gynecol. 181. 2. 359-66

Blanks, A. M. and Thornton, S. 2003. The role of oxytocin in parturition. BJOG. 110 Suppl 20. 46-51

Blanks, A. M., Vatish, M., Allen, M. J., Ladds, G., de Wit, N. C., Slater, D. M. and Thornton, S. 2003. Paracrine oxytocin and estradiol demonstrate a spatial increase in human intrauterine tissues with labor. J Clin Endocrinol Metab. 88. 7. 3392-400

Boroditsky, R. S., Reyes, F. I., Winter, J. S. and Faiman, C. 1978. Maternal serum estrogen and progesterone concentrations preceding normal labor. Obstet Gynecol. 51. 6. 686-91

Campbell, E. A., Linton, E. A., Wolfe, C. D., Scraggs, P. R., Jones, M. T. and Lowry, P. J. 1987. Plasma corticotropin-releasing hormone concentrations during pregnancy and parturition. J Clin Endocrinol Metab. 64. 5. 1054-9 
Challis, J. R., Lockwood, C. J., Myatt, L., Norman, J. E., Strauss, J. F., 3rd and Petraglia, F. 2009. Inflammation and pregnancy. Reprod Sci. 16. 2. 206-15

Chapman, N. R., Europe-Finner, G. N. and Robson, S. C. 2004. Expression and deoxyribonucleic acid-binding activity of the nuclear factor kappaB family in the human myometrium during pregnancy and labor. J Clin Endocrinol Metab. 89. 11. 5683-93

Condon, J. C., Jeyasuria, P., Faust, J. M., Wilson, J. W. and Mendelson, C. R. 2003. A decline in the levels of progesterone receptor coactivators in the pregnant uterus at term may antagonize progesterone receptor function and contribute to the initiation of parturition. Proc Natl Acad Sci U S A. 100. 16. 9518-23

Condon, J. C., Hardy, D. B., Kovaric, K. and Mendelson, C. R. 2006. Up-regulation of the progesterone receptor (PR)-C isoform in laboring myometrium by activation of nuclear factor-kappaB may contribute to the onset of labor through inhibition of PR function. Mol Endocrinol. 20. 4. 764-75

da Fonseca, E. B., Bittar, R. E., Carvalho, M. H. and Zugaib, M. 2003. Prophylactic administration of progesterone by vaginal suppository to reduce the incidence of spontaneous preterm birth in women at increased risk: a randomized placebocontrolled double-blind study. Am J Obstet Gynecol. 188. 2. 419-24

Dodd, J. M., Flenady, V. J., Cincotta, R. and Crowther, C. A. 2008. Progesterone for the prevention of preterm birth: a systematic review. Obstet Gynecol. 112. 1. 127-34

Dudley, D. J. 1999. Immunoendocrinology of preterm labor: the link between corticotropin-releasing hormone and inflammation. Am J Obstet Gynecol. 180. 1 Pt 3. S251-6

El Khwad, M., Stetzer, B., Moore, R. M., Kumar, D., Mercer, B., Arikat, S., Redline, R. W., Mansour, J. M. and Moore, J. J. 2005. Term human fetal membranes have a weak zone overlying the lower uterine pole and cervix before onset of labor. Biol Reprod. 72. 3. 720-6

Elliott, C. L., Slater, D. M., Dennes, W., Poston, L. and Bennett, P. R. 2000. Interleukin 8 expression in human myometrium: changes in relation to labor onset and with gestational age. Am J Reprod Immunol. 43. 5. 272-7

Elliott, C. L., Allport, V. C., Loudon, J. A., Wu, G. D. and Bennett, P. R. 2001. Nuclear factor-kappa B is essential for up-regulation of interleukin-8 expression in human amnion and cervical epithelial cells. Mol Hum Reprod. 7. 8. 787-90

Elovitz, M. A., Wang, Z., Chien, E. K., Rychlik, D. F. and Phillippe, M. 2003. A new model for inflammation-induced preterm birth: the role of platelet-activating factor and Toll-like receptor-4. Am J Pathol. 163. 5. 2103-11

Fidel, P. L., Jr., Romero, R., Wolf, N., Cutright, J., Ramirez, M., Araneda, H. and Cotton, D. B. 1994. Systemic and local cytokine profiles in endotoxin-induced preterm parturition in mice. Am J Obstet Gynecol. 170. 5 Pt 1. 1467-75

Fonseca, E. B., Celik, E., Parra, M., Singh, M. and Nicolaides, K. H. 2007. Progesterone and the risk of preterm birth among women with a short cervix. N Engl $\mathbf{J}$ Med. 357. 5. 462-9

Friebe-Hoffmann, U., Chiao, J. P. and Rauk, P. N. 2001. Effect of IL-1beta and IL-6 on oxytocin secretion in human uterine smooth muscle cells. Am J Reprod Immunol. 46. 3. 226-31

Fuchs, A. R., Fuchs, F., Husslein, P. and Soloff, M. S. 1984. Oxytocin receptors in the human uterus during pregnancy and parturition. Am J Obstet Gynecol. 150. 6. 734-41 Fuchs, F. and Stakemann, G. 1960. Treatment of threatened premature labor with large doses of progesterone. Am J Obstet Gynecol. 79. 172-6 
Goldenberg, R. L., Culhane, J. F., Iams, J. D. and Romero, R. 2008. Epidemiology and causes of preterm birth. Lancet. 371. 9606. 75-84

Gotkin, J. L., Celver, J., McNutt, P., Shields, A. D., Howard, B. C., Paonessa, D. J. and Napolitano, P. G. 2006. Progesterone reduces lipopolysaccharide induced interleukin-6 secretion in fetoplacental chorionic arteries, fractionated cord blood, and maternal mononuclear cells. Am J Obstet Gynecol. 195. 4. 1015-9

Grammatopoulos, D., Milton, N. G. and Hillhouse, E. W. 1994. The human myometrial CRH receptor: G proteins and second messengers. Mol Cell Endocrinol. 99. 2. 245-50

Grammatopoulos, D., Thompson, S. and Hillhouse, E. W. 1995. The human myometrium expresses multiple isoforms of the corticotropin-releasing hormone receptor. J Clin Endocrinol Metab. 80. 8. 2388-93

Grammatopoulos, D. K. and Hillhouse, E. W. 1999a. Role of corticotropin-releasing hormone in onset of labour. Lancet. 354. 9189. 1546-9

Grammatopoulos, D. K. and Hillhouse, E. W. 1999b. Activation of protein kinase C by oxytocin inhibits the biological activity of the human myometrial corticotropinreleasing hormone receptor at term. Endocrinology. 140. 2. 585-94

Hapangama, D. and Neilson, J. P. 2009. Mifepristone for induction of labour. Cochrane Database Syst Rev. 3. CD002865

Hatthachote, P. and Gillespie, J. I. 1999. Complex interactions between sex steroids and cytokines in the human pregnant myometrium: evidence for an autocrine signaling system at term. Endocrinology. 140. 6. 2533-40

Hertelendy, F., Romero, R., Molnar, M., Todd, H. and Baldassare, J. J. 1993. Cytokine-initiated signal transduction in human myometrial cells. Am J Reprod Immunol. 30. 2-3. 49-57

Hertelendy, F. and Zakar, T. 2004. Prostaglandins and the myometrium and cervix. Prostaglandins Leukot Essent Fatty Acids. 70. 2. 207-22

Irwin, M., Hauger, R. L., Jones, L., Provencio, M. and Britton, K. T. 1990. Sympathetic nervous system mediates central corticotropin-releasing factor induced suppression of natural killer cytotoxicity. J Pharmacol Exp Ther. 255. 1. 101-7

Ito, A., Sato, T., Ojima, Y., Chen, L. C., Nagase, H. and Mori, Y. 1991. Calmodulin differentially modulates the interleukin 1-induced biosynthesis of tissue inhibitor of metalloproteinases and matrix metalloproteinases in human uterine cervical fibroblasts. J Biol Chem. 266. 21. 13598-601

Jain, R., Zwickler, D., Hollander, C. S., Brand, H., Saperstein, A., Hutchinson, B., Brown, C. and Audhya, T. 1991. Corticotropin-releasing factor modulates the immune response to stress in the rat. Endocrinology. 128. 3. 1329-36

Johnston, T. A., Greer, I. A., Kelly, R. W. and Calder, A. A. 1993. Plasma prostaglandin metabolite concentrations in normal and dysfunctional labour. $\mathrm{Br} \mathbf{J}$ Obstet Gynaecol. 100. 5. 483-8

Kalantaridou, S. N., Makrigiannakis, A., Zoumakis, E. and Chrousos, G. P. 2004. Reproductive functions of corticotropin-releasing hormone. Research and potential clinical utility of antalarmins (CRH receptor type 1 antagonists). Am J Reprod Immunol. 51. 4. 269-74

Kamada, M., Irahara, M., Maegawa, M., Ohmoto, Y., Murata, K., Yasui, T., Yamano, S. and Aono, T. 2001. Transient increase in the levels of T-helper 1 cytokines in postmenopausal women and the effects of hormone replacement therapy. Gynecol Obstet Invest. 52. 2. 82-8

Kanda, N. and Tamaki, K. 1999. Estrogen enhances immunoglobulin production by human PBMCs. J Allergy Clin Immunol. 103. 2 Pt 1. 282-8 
Keck, C., Herchenbach, D., Pfisterer, J. and Breckwoldt, M. 1998. Effects of 17betaestradiol and progesterone on interleukin-6 production and proliferation of human umbilical vein endothelial cells. Exp Clin Endocrinol Diabetes. 106. 4. 334-9

Kelly, R. W. 2002. Inflammatory mediators and cervical ripening. J Reprod Immunol. 57. 1-2. 217-24

Kikuchi, N., Urabe, M., Iwasa, K., Okubo, T., Tsuchiya, H., Hosoda, T., Tatsumi, H. and Honjo, H. 2000. Atheroprotective effect of estriol and estrone sulfate on human vascular smooth muscle cells. J Steroid Biochem Mol Biol. 72. 1-2. 71-8

Kniss, D. A., Rovin, B., Fertel, R. H. and Zimmerman, P. D. 2001. Blockade NFkappaB activation prohibits TNF-alpha-induced cyclooxygenase-2 gene expression in ED27 trophoblast-like cells. Placenta. 22. 1. 80-9

Kumar, D., Fung, W., Moore, R. M., Pandey, V., Fox, J., Stetzer, B., Mansour, J. M., Mercer, B. M., Redline, R. W. and Moore, J. J. 2006. Proinflammatory cytokines found in amniotic fluid induce collagen remodeling, apoptosis, and biophysical weakening of cultured human fetal membranes. Biol Reprod. 74. 1. 29-34

Laatikainen, T. J., Raisanen, I. J. and Salminen, K. R. 1988. Corticotropin-releasing hormone in amniotic fluid during gestation and labor and in relation to fetal lung maturation. Am J Obstet Gynecol. 159. 4. 891-5

Lappas, M., Permezel, M., Georgiou, H. M. and Rice, G. E. 2002. Nuclear factor kappa B regulation of proinflammatory cytokines in human gestational tissues in vitro. Biol Reprod. 67. 2. 668-73

Ledingham, M. A., Thomson, A. J., Jordan, F., Young, A., Crawford, M. and Norman, J. E. 2001. Cell adhesion molecule expression in the cervix and myometrium during pregnancy and parturition. Obstet Gynecol. 97. 2. 235-42

Linton, E. A., Perkins, A. V., Woods, R. J., Eben, F., Wolfe, C. D., Behan, D. P., Potter, E., Vale, W. W. and Lowry, P. J. 1993. Corticotropin releasing hormonebinding protein $(\mathrm{CRH}-\mathrm{BP})$ : plasma levels decrease during the third trimester of normal human pregnancy. J Clin Endocrinol Metab. 76. 1. 260-2

March of Dimes 2009. March of Dimes White paper on Preterm Birth. The Global and Regional Toll. White Plains, New York.

Maret, A., Coudert, J. D., Garidou, L., Foucras, G., Gourdy, P., Krust, A., Dupont, S., Chambon, P., Druet, P., Bayard, F. and Guery, J. C. 2003. Estradiol enhances primary antigen-specific CD4 T cell responses and Th1 development in vivo. Essential role of estrogen receptor alpha expression in hematopoietic cells. Eur J Immunol. 33. 2. 51221

Martin, J. A., Hamilton, B. E., Sutton, P. D., Ventura, S. J., Menacker, F. and Kirmeyer, S. 2006. Births: final data for 2004. Natl Vital Stat Rep. 55. 1. 1-101

Mathur, R. S., Landgrebe, S. and Williamson, H. O. 1980. Progesterone, 17hydroxyprogesterone, estradiol, and estriol in late pregnancy and labor. Am J Obstet Gynecol. 136. 1. 25-7

McLaren, J., Malak, T. M. and Bell, S. C. 1999. Structural characteristics of term human fetal membranes prior to labour: identification of an area of altered morphology overlying the cervix. Hum Reprod. 14. 1. 237-41

McLean, M., Bisits, A., Davies, J., Woods, R., Lowry, P. and Smith, R. 1995. A placental clock controlling the length of human pregnancy. Nat Med. 1. 5. 460-3

Meis, P. J., Klebanoff, M., Thom, E., Dombrowski, M. P., Sibai, B., Moawad, A. H., Spong, C. Y., Hauth, J. C., Miodovnik, M., Varner, M. W., Leveno, K. J., Caritis, S. N., Iams, J. D., Wapner, R. J., Conway, D., O'Sullivan, M. J., Carpenter, M., Mercer, B., Ramin, S. M., Thorp, J. M., Peaceman, A. M. and Gabbe, S. 2003. Prevention of 
recurrent preterm delivery by 17 alpha-hydroxyprogesterone caproate. N Engl J Med. 348. 24. 2379-85

Merlino, A. A., Welsh, T. N., Tan, H., Yi, L. J., Cannon, V., Mercer, B. M. and Mesiano, S. 2007. Nuclear progesterone receptors in the human pregnancy myometrium: evidence that parturition involves functional progesterone withdrawal mediated by increased expression of progesterone receptor-A. J Clin Endocrinol Metab. 92. 5. 1927-33

Mesiano, S., Chan, E. C., Fitter, J. T., Kwek, K., Yeo, G. and Smith, R. 2002. Progesterone withdrawal and estrogen activation in human parturition are coordinated by progesterone receptor A expression in the myometrium. J Clin Endocrinol Metab. 87. 6. 2924-30

Mitchell, B. F. and Wong, S. 1993. Changes in 17 beta,20 alpha-hydroxysteroid dehydrogenase activity supporting an increase in the estrogen/progesterone ratio of human fetal membranes at parturition. Am J Obstet Gynecol. 168. 5. 1377-85

Mitchell, B. F. and Taggart, M. J. 2009. Are animal models relevant to key aspects of human parturition? Am J Physiol Regul Integr Comp Physiol. 297. 3. R525-45

Molnar, M., Romero, R. and Hertelendy, F. 1993. Interleukin-1 and tumor necrosis factor stimulate arachidonic acid release and phospholipid metabolism in human myometrial cells. Am J Obstet Gynecol. 169. 4. 825-9

Nishimori, K., Young, L. J., Guo, Q., Wang, Z., Insel, T. R. and Matzuk, M. M. 1996. Oxytocin is required for nursing but is not essential for parturition or reproductive behavior. Proc Natl Acad Sci U S A. 93. 21. 11699-704

Norman, J. E., Mackenzie, F., Owen, P., Mactier, H., Hanretty, K., Cooper, S., Calder, A., Mires, G., Danielian, P., Sturgiss, S., MacLennan, G., Tydeman, G., Thornton, S., Martin, B., Thornton, J. G., Neilson, J. P. and Norrie, J. 2009a. Progesterone for the prevention of preterm birth in twin pregnancy (STOPPIT): a randomised, double-blind, placebo-controlled study and meta-analysis. Lancet. 373. 9680. 2034-40

Norman, J. E., Morris, C. and Chalmers, J. 2009b. The effect of changing patterns of obstetric care in Scotland (1980-2004) on rates of preterm birth and its neonatal consequences: perinatal database study. PLoS Med. 6. 9. e1000153

Osman, I., Young, A., Ledingham, M. A., Thomson, A. J., Jordan, F., Greer, I. A. and Norman, J. E. 2003. Leukocyte density and pro-inflammatory cytokine expression in human fetal membranes, decidua, cervix and myometrium before and during labour at term. Mol Hum Reprod. 9. 1. 41-5

Peltier, M. R. 2003. Immunology of term and preterm labor. Reprod Biol Endocrinol. 1. 122

Pirianov, G., Waddington, S. N., Lindstrom, T. M., Terzidou, V., Mehmet, H. and Bennett, P. R. 2009. The cyclopentenone 15-deoxy-delta 12,14-prostaglandin J(2) delays lipopolysaccharide-induced preterm delivery and reduces mortality in the newborn mouse. Endocrinology. 150. 2. 699-706

Polan, M. L., Loukides, J., Nelson, P., Carding, S., Diamond, M., Walsh, A. and Bottomly, K. 1989. Progesterone and estradiol modulate interleukin-1 beta messenger ribonucleic acid levels in cultured human peripheral monocytes. J Clin Endocrinol Metab. 69. 6. 1200-6

Rauk, P. N. and Chiao, J. P. 2000. Interleukin-1 stimulates human uterine prostaglandin production through induction of cyclooxygenase-2 expression. Am $\mathbf{J}$ Reprod Immunol. 43. 3. 152-9 
Rauk, P. N. and Friebe-Hoffmann, U. 2000. Interleukin-1 beta down-regulates the oxytocin receptor in cultured uterine smooth muscle cells. Am J Reprod Immunol. 43. 2. 85-91

Rauk, P. N., Friebe-Hoffmann, U., Winebrenner, L. D. and Chiao, J. P. 2001. Interleukin-6 up-regulates the oxytocin receptor in cultured uterine smooth muscle cells. Am J Reprod Immunol. 45. 3. 148-53

Riley, S. C., Leask, R., Chard, T., Wathen, N. C., Calder, A. A. and Howe, D. C. 1999. Secretion of matrix metalloproteinase-2, matrix metalloproteinase- 9 and tissue inhibitor of metalloproteinases into the intrauterine compartments during early pregnancy. Mol Hum Reprod. 5. 4. 376-81

Robinson, B. G., Emanuel, R. L., Frim, D. M. and Majzoub, J. A. 1988. Glucocorticoid stimulates expression of corticotropin-releasing hormone gene in human placenta. Proc Natl Acad Sci U S A. 85. 14. 5244-8

Robinson, B. G., Arbiser, J. L., Emanuel, R. L. and Majzoub, J. A. 1989. Speciesspecific placental corticotropin releasing hormone messenger RNA and peptide expression. Mol Cell Endocrinol. 62. 2. 337-41

Rodriguez, E., Lopez, R., Paez, A., Masso, F. and Montano, L. F. 2002. 17Betaestradiol inhibits the adhesion of leukocytes in TNF-alpha stimulated human endothelial cells by blocking IL-8 and MCP-1 secretion, but not its transcription. Life Sci. 71. 18. 2181-93

Rodts-Palenik, S., Wyatt-Ashmead, J., Pang, Y., Thigpen, B., Cai, Z., Rhodes, P., Martin, J. N., Granger, J. and Bennett, W. A. 2004. Maternal infection-induced white matter injury is reduced by treatment with interleukin-10. Am J Obstet Gynecol. 191. 4. 1387-92

Rogers, A. and Eastell, R. 2001. The effect of 17beta-estradiol on production of cytokines in cultures of peripheral blood. Bone. 29. 1. 30-4

Romero, R., Sibai, B. M., Sanchez-Ramos, L., Valenzuela, G. J., Veille, J. C., Tabor, B., Perry, K. G., Varner, M., Goodwin, T. M., Lane, R., Smith, J., Shangold, G. and Creasy, G. W. 2000. An oxytocin receptor antagonist (atosiban) in the treatment of preterm labor: a randomized, double-blind, placebo-controlled trial with tocolytic rescue. Am J Obstet Gynecol. 182. 5. 1173-83

Salas, M. A., Brown, O. A., Perone, M. J., Castro, M. G. and Goya, R. G. 1997. Effect of the corticotrophin releasing hormone precursor on interleukin-6 release by human mononuclear cells. Clin Immunol Immunopathol. 85. 1. 35-9

Sayeed, I. and Stein, D. G. 2009. Progesterone as a neuroprotective factor in traumatic and ischemic brain injury. Prog Brain Res. 175. 219-37

Schmid, B., Wong, S. and Mitchell, B. F. 2001. Transcriptional regulation of oxytocin receptor by interleukin-1beta and interleukin-6. Endocrinology. 142. 4. 1380-5

Seaman, W. E. and Gindhart, T. D. 1979. Effect of estrogen on natural killer cells. Arthritis Rheum. 22. 11. 1234-40

Sennstrom, M. B., Ekman, G., Westergren-Thorsson, G., Malmstrom, A., Bystrom, B., Endresen, U., Mlambo, N., Norman, M., Stabi, B. and Brauner, A. 2000. Human cervical ripening, an inflammatory process mediated by cytokines. Mol Hum Reprod. 6. 4. 375-81

Shynlova, O., Tsui, P., Dorogin, A. and Lye, S. J. 2008. Monocyte chemoattractant protein-1 (CCL-2) integrates mechanical and endocrine signals that mediate term and preterm labor. J Immunol. 181. 2. 1470-9

Simhan, H. N. and Caritis, S. N. 2007. Prevention of preterm delivery. N Engl J Med. 357. 5. 477-87 
Slater, D. M., Dennes, W. J., Campa, J. S., Poston, L. and Bennett, P. R. 1999. Expression of cyclo-oxygenase types- 1 and -2 in human myometrium throughout pregnancy. Mol Hum Reprod. 5. 9. 880-4

Smith, R. 2007. Parturition. N Engl J Med. 356. 3. 271-83

Smith, R., Smith, J. I., Shen, X., Engel, P. J., Bowman, M. E., McGrath, S. A., Bisits, A. M., McElduff, P., Giles, W. B. and Smith, D. W. 2009. Patterns of plasma corticotropin-releasing hormone, progesterone, estradiol, and estriol change and the onset of human labor. J Clin Endocrinol Metab. 94. 6. 2066-74

Straub, R. H. 2007. The complex role of estrogens in inflammation. Endocr Rev. 28. 5. 521-74

Terrone, D. A., Rinehart, B. K., Granger, J. P., Barrilleaux, P. S., Martin, J. N., Jr. and Bennett, W. A. 2001. Interleukin-10 administration and bacterial endotoxin-induced preterm birth in a rat model. Obstet Gynecol. 98. 3. 476-80

Terzidou, V., Lee, Y., Lindstrom, T., Johnson, M., Thornton, S. and Bennett, P. R. 2006. Regulation of the human oxytocin receptor by nuclear factor-kappaB and CCAAT/enhancer-binding protein-beta. J Clin Endocrinol Metab. 91. 6. 2317-26

Thomas, J. P., S. 2001. The National Sentinel Caesarean Section Audit Report. London.

Thomson, A. J., Telfer, J. F., Young, A., Campbell, S., Stewart, C. J., Cameron, I. T., Greer, I. A. and Norman, J. E. 1999. Leukocytes infiltrate the myometrium during human parturition: further evidence that labour is an inflammatory process. Hum Reprod. 14. 1. 229-36

Thornton, S., Davison, J. M. and Baylis, P. H. 1992. Plasma oxytocin during the first and second stages of spontaneous human labour. Acta Endocrinol (Copenh). 126. 5. 425-9

Tribe, R. M., Moriarty, P., Dalrymple, A., Hassoni, A. A. and Poston, L. 2003. Interleukin-1beta induces calcium transients and enhances basal and store operated calcium entry in human myometrial smooth muscle. Biol Reprod. 68. 5. 1842-9

Tulchinsky, D., Hobel, C. J., Yeager, E. and Marshall, J. R. 1972. Plasma estrone, estradiol, estriol, progesterone, and 17-hydroxyprogesterone in human pregnancy. I. Normal pregnancy. Am J Obstet Gynecol. 112. 8. 1095-100

Turnbull, A. C., Patten, P. T., Flint, A. P., Keirse, M. J., Jeremy, J. Y. and Anderson, A. B. 1974. Significant fall in progesterone and rise in oestradiol levels in human peripheral plasma before onset of labour. Lancet. 1. 7848. 101-3

Vadillo-Ortega, F., Gonzalez-Avila, G., Furth, E. E., Lei, H., Muschel, R. J., StetlerStevenson, W. G. and Strauss, J. F., 3rd. 1995. 92-kd type IV collagenase (matrix metalloproteinase-9) activity in human amniochorion increases with labor. Am J Pathol. 146. 1. 148-56

Wadhwa, P. D., Porto, M., Garite, T. J., Chicz-DeMet, A. and Sandman, C. A. 1998. Maternal corticotropin-releasing hormone levels in the early third trimester predict length of gestation in human pregnancy. Am J Obstet Gynecol. 179. 4. 1079-85

Wadhwa, P. D., Culhane, J. F., Rauh, V. and Barve, S. S. 2001. Stress and preterm birth: neuroendocrine, immune/inflammatory, and vascular mechanisms. Matern Child Health J. 5. 2. 119-25

Wang, H. and Hirsch, E. 2003. Bacterially-induced preterm labor and regulation of prostaglandin-metabolizing enzyme expression in mice: the role of toll-like receptor 4. Biol Reprod. 69. 6. 1957-63

Watari, M., Watari, H., DiSanto, M. E., Chacko, S., Shi, G. P. and Strauss, J. F., 3rd. 1999. Pro-inflammatory cytokines induce expression of matrix-metabolizing enzymes in human cervical smooth muscle cells. Am J Pathol. 154. 6. 1755-62 
Winkler, M., Fischer, D. C., Ruck, P., Horny, H. P., Kemp, B. and Rath, W. 1998. [Cytokine concentrations and expression of adhesion molecules in the lower uterine segment during parturition at term: relation to cervical dilatation and duration of labor]. Z Geburtshilfe Neonatol. 202. 4. 172-5

Young, A., Thomson, A. J., Ledingham, M., Jordan, F., Greer, I. A. and Norman, J. E. 2002. Immunolocalization of proinflammatory cytokines in myometrium, cervix, and fetal membranes during human parturition at term. Biol Reprod. 66. 2. 445-9

Young, W. S., 3rd, Shepard, E., Amico, J., Hennighausen, L., Wagner, K. U., LaMarca, M. E., McKinney, C. and Ginns, E. I. 1996. Deficiency in mouse oxytocin prevents milk ejection, but not fertility or parturition. J Neuroendocrinol. 8. 11. 84753

Youssef, R. E., Ledingham, M. A., Bollapragada, S. S., O'Gorman, N., Jordan, F., Young, A. and Norman, J. E. 2009. The Role of Toll-Like Receptors (TLR-2 and -4) and Triggering Receptor Expressed on Myeloid Cells 1 (TREM-1) in Human Term and Preterm Labor. Reprod Sci.

Yuan, M., Jordan, F., McInnes, I. B., Harnett, M. M. and Norman, J. E. 2009. Leukocytes are primed in peripheral blood for activation during term and preterm labour. Mol Hum Reprod. 
Figure 1

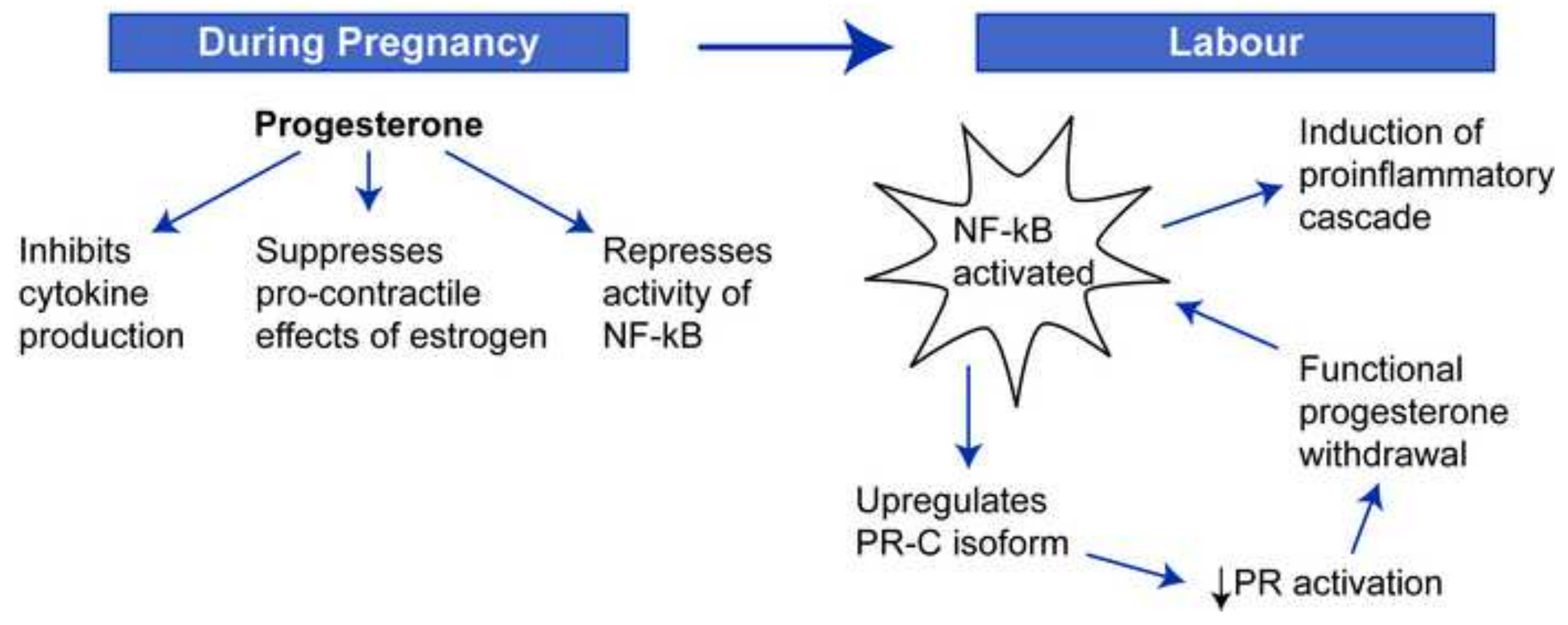


Figure 2

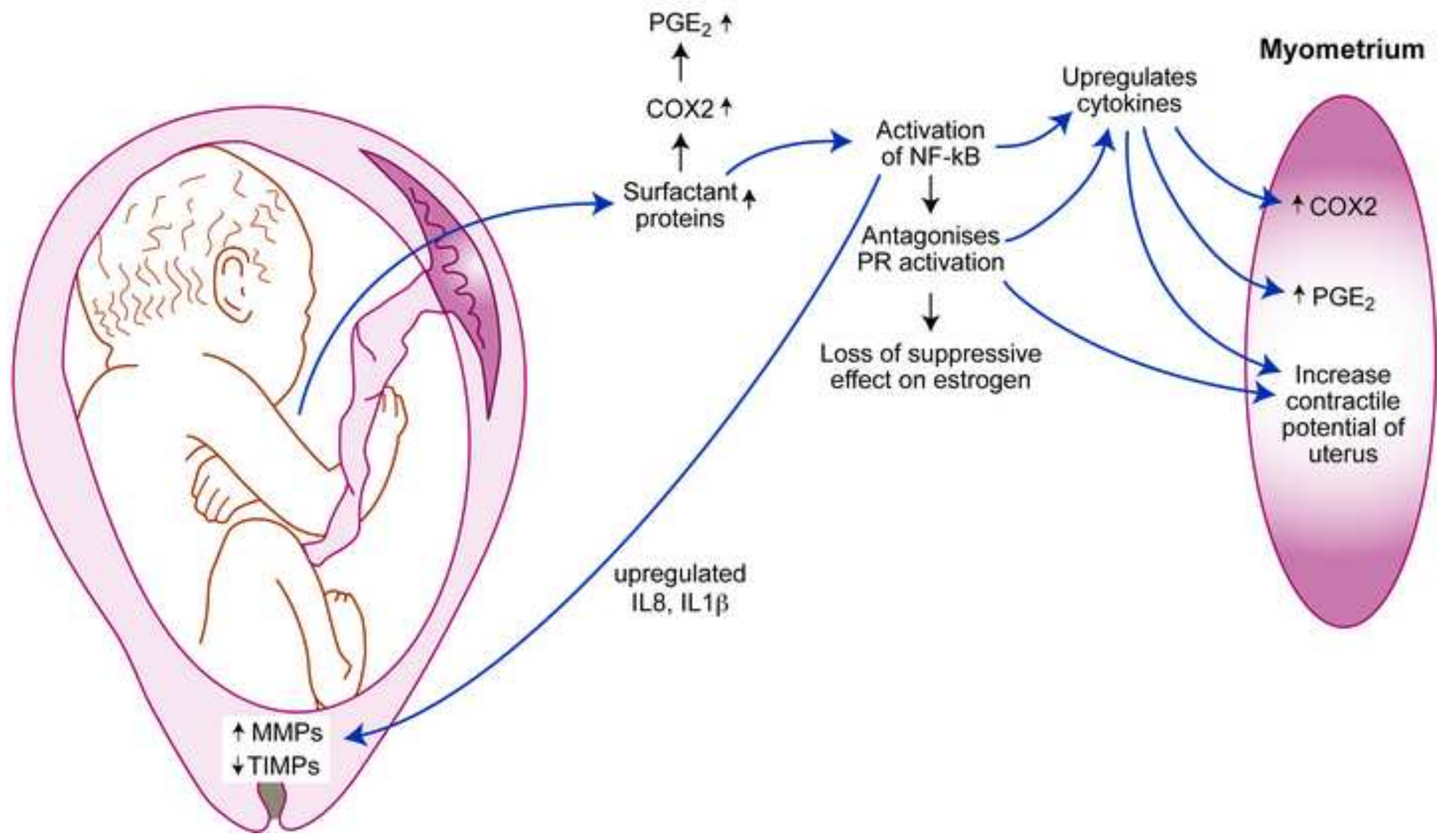

